Most Swahilis have only a shadowy conception of what a whale is ; to them it is a great snake which devours men and even boats. When God is angry with one of these beasts, he lets down a rope by which the monster is caught and drawn struggling to heaven.

Mpapua, Tanganyika Territory,

H. E. HORNBY. November $2 \mathrm{I}$

\section{The Cause of Anticyclones.}

In NATURE of December 23, I922, p. 845, Mr. W. H. Dines points out that the main features of the pressure distribution of the atmosphere are of a permanent character, and, strange to say, the great areas of low pressure are over the cold poles, while the two belts of high pressure are on both sides of the equator in latitudes $30^{\circ}$ or thereabouts; and, so far as the troposphere is concerned, the atmosphere is warm over areas of high pressure. Mr. Dines remarks, 'The difficulty should be faced and not ignored.'

At the Royal Society, on November 23 last, I had the pleasure of hearing a paper read by Lindemann and Dobson, who have succeeded in determining the temperature of the upper atmosphere (stratosphere) by observations of the luminosity of meteors. They estimate that at a height of $60 \mathrm{~km}$. the temperature of the air is in the neighbourhood of $300^{\circ} \mathrm{Abs}$.

In a paper communicated to the Phil. Mag. (vol. xxxv., March I9I 8, p. 233) I gave a diagram showing the probable temperature of the atmosphere between the poles and the equator up to heights of $70 \mathrm{~km}$. This diagram was constructed by plotting the temperatures ascertained by sending up self-registering balloons, and extrapolating for greater heights. At the poles the temperature arrived at was about $285^{\circ} \mathrm{Abs}$. at $60 \mathrm{~km}$. In the paper referred to I concluded that the stratosphere over the poles and equator is much hotter than it is over the high pressure belts at latitudes $30^{\circ} \mathrm{N}$. and $\mathrm{S}$. of the equator $-20^{\circ} \mathrm{C}$. or more-and suggested that the winds of the earth are very largely affected by these differences of temperature.

The temperature values found by Lindemann and Dobson showed considerable variations when the results obtained by one falling star were compared with another. I would suggest that the several results they obtained be plotted on a diagram, the ordinates being temperatures at $60 \mathrm{~km}$. and the abscissæ barometric pressures. Knowing the time and position of each falling star, the pressures could be obtained from meteorological charts. My suggestion was that the upper atmosphere is hotter over low pressure areas than it is over high pressure areas.

R. M. DEELEY.

Tintagil, Kew Gardens Road, Kew, Surrey, December. 27.

\section{Soil Reaction, Water Snails, and Liver Flukes.}

In NATuRE of November 25, p. 7or, Dr. Monica Taylor mentions. that the distribution of Limncea truncatula in S.W. Scotland is very local, being rare or altogether absent from certain districts in which sheep are known to be infected with liver flukes. In such districts $L$. peregra is found infected with perfectly developed cercariæ of Fasciola hepatica. Free active cercariæ of the latter are also found.

In NATURE of December 23, p. 845, Mr. R. Hedger Wallace directs attention to the prevalence of liver fluke disease in the Swansea valley, where rough pastures have been limed. He asks, "Does liming a wet sour pasture make it more congenial to the water snail ?"

$$
\text { NO. } 2777 \text {, VOL. I I I] }
$$

For the past year, as occasion permitted, we have been engaged upon the study of the distribution of snail species in relation to the hydrogen ion concentration of the soil and water. A very striking limitation is found for certain species, and but few are found in the more acid habitats. Thus, over quartzite at $p_{4} \cdot 8$, nothing but a few Hyalinias could be found, whereas around $p \mathrm{H}_{7}$ numerous species exist, including $L$. truncatula. Fewer species are found at $p \mathrm{H} 8$, but those that do are often in great numbers, Helicella caperata and more especially $H$. virgata. Upland peat soil is usually close to $\mathrm{pH}_{4} \cdot 6$, and rough pastures may be between that and $p^{\mathrm{H}_{5}} \cdot 4$ or somewhat over, so it seems highly probable that liming such land, by bringing it to the neighbourhood of $p \mathrm{H}_{7}$, does make the conditions more favourable for the snails concerned in the transmission of the disease.

In cases where certain sheep in a flock are infected, it would seem advisable to drive the flock to the most acid soil available, provided it is strongly acid, for in such a site the infected sheep will not be able to infect others, and so the disease may be stamped out or reduced in amount.

Where the neutral or slightly acid soil which appears to favour the occurrence of liver fluke disease is wanting, transference to chalk or limestone soil, at about $p \mathrm{H} 8$, may perhaps be equally effective; but it must be remembered that, owing to leaching by rain, the steep places in such districts may be less alkaline, or even acid.

It is very desirable that the limits of distribution of $L$. truncatula and $L$. peregra should be defined in relation to the reaction of the soil and water, and the writers would be glad to receive samples of soil from infected and uninfected localities.

The distribution of snails in relation to soil reaction is similar to that of plants, and it may be added that there is a widespread belief in the west of Ireland that liver fluke disease is caused by eating a certain plant found in fields where the disease has been known to occur. The Gaelic name of the plant was mentioned to one of us, but, unfortunately, it has been forgotten. The distribution of the plant may serve as a guide to the distribution of the snails in question.

$$
\text { W. R. G. Atrins. }
$$

M. V. Lebour.

Marine Biological Laboratory, Plymouth, December 28.

\section{Amber and the Dammar of Living Bees.}

In the issue of NATURE for June 3, I922 (vol. Io9, p. 713), a letter is published from Prof. T. D. A. Cockerell, of the University of Colorado, on "Fossils in Burmese Amber." This refers mainly to amber obtained from the amber mines in the Hukong Valley, which I visited in February I92I. In that letter Prof. Cockerell, after investigating the insects preserved in specimens of the amber, agrees with me in placing the age of the amber-bearing beds as the earlier part of the middle Eocene, there being no doubt that the Nummulites found by me are actually Nummulites biaritzensis d'Arch.

In the second part of his letter, however, Prof. Cockerell introduces a new problem. In addition to the specimens from the Hukong Valley amber mines, he mentions a number of beads of extremely pale and pellucid amber which he afterwards received from Mr. R. C. J. Swinhoe, of Mandalay. These contained well-preserved insects all different from those identified in the amber from the Hukong Valley mines. Mr. Swinhoe was uncertain whether these beads were Burmese amber or whether they had been imported from China. Prof. Cockerell, after 